2013-04

Relative sensitivity of two marine bivalves for detection of genotoxic and cytotoxic effects: a field assessment in the Tamar Estuary, South West England

Dallas, LJ

http://hdl.handle.net/10026.1/17774

10.1007/s10661-012-2800-0

Environmental Monitoring and Assessment

Springer Science and Business Media LLC

All content in PEARL is protected by copyright law. Author manuscripts are made available in accordance with publisher policies. Please cite only the published version using the details provided on the item record or document. In the absence of an open licence (e.g. Creative Commons), permissions for further reuse of content should be sought from the publisher or author. 
See discussions, stats, and author profiles for this publication at: https://www.researchgate.net/publication/230666360

Relative sensitivity of two marine bivalves for detection of genotoxic and cytotoxic effects: A field assessment in the Tamar Estuary, South West England

Article in Environmental Monitoring and Assessment · August 2012

DOI: 10.1007/s10661-012-2800-0 · Source: PubMed

CITATIONS

26

4 authors:

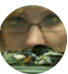

Lorna J Dallas

University of Plymouth

25 PUBLICATIONS 457 CITATIONS

SEE PROFILE

Andrew Simon Fisher

University of Plymouth

99 PUBLICATIONS 2,854 CITATIONS

SEE PROFILE

Some of the authors of this publication are also working on these related projects:

GCRF Blue Communities View project

The Trojan Horses project View project
READS

166

Victoria Cheung

University of Plymouth

11 PUBLICATIONS 337 CITATIONS

SEE PROFILE

Awadhesh N Jha

University of Plymouth

142 PUBlicATIONS 6,855 CITATIONS

SEE PROFILE 
Relative sensitivity of two marine bivalves for detection of genotoxic and cytotoxic effects: a field assessment in the Tamar Estuary, South West England

\section{Lorna J. Dallas, Victoria V. Cheung, Andrew S. Fisher \& Awadhesh N. Jha}

Environmental Monitoring and Assessment

An International Journal Devoted to Progress in the Use of Monitoring Data in Assessing Environmental Risks to Man and the Environment

ISSN 0167-6369

Environ Monit Assess

DOI 10.1007/s10661-012-2800-0

\section{ENVIRONME FIRST MONITORING AND ASSESSMENT}

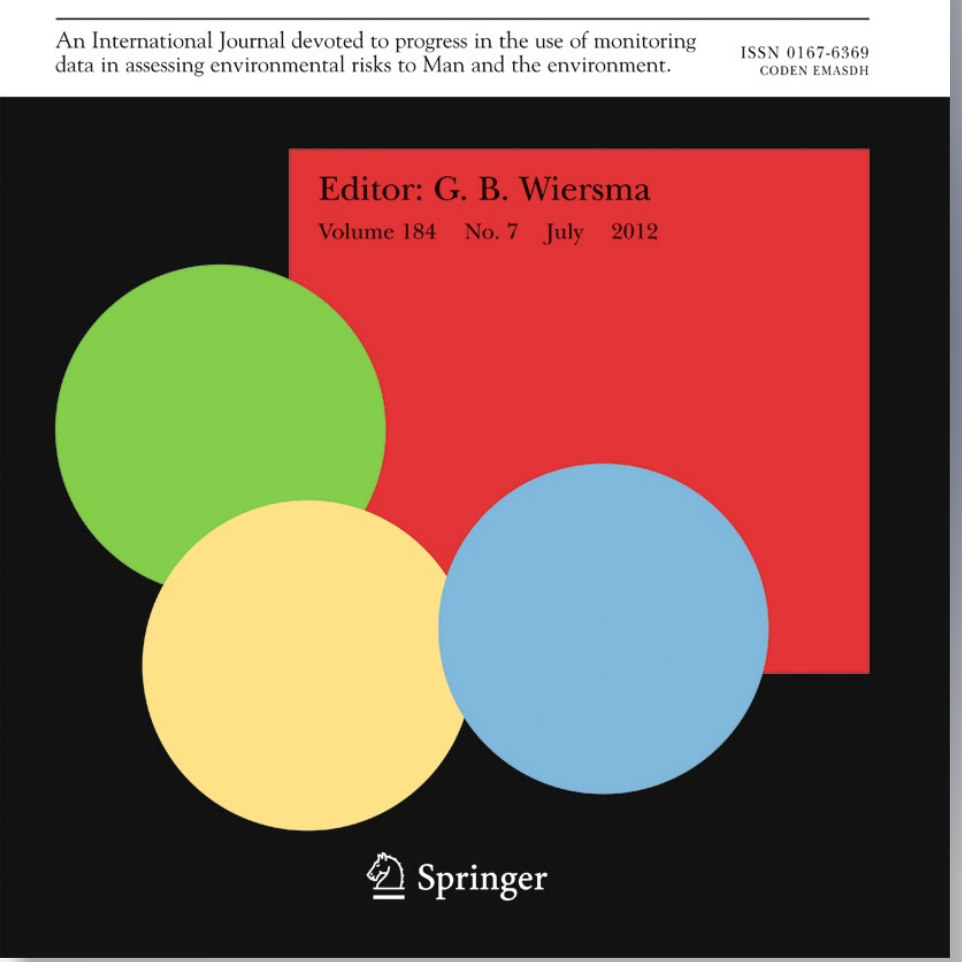

\section{照 Springer}


Your article is protected by copyright and all rights are held exclusively by Springer Science+Business Media B.V.. This e-offprint is for personal use only and shall not be selfarchived in electronic repositories. If you wish to self-archive your work, please use the accepted author's version for posting to your own website or your institution's repository. You may further deposit the accepted author's version on a funder's repository at a funder's request, provided it is not made publicly available until 12 months after publication. 


\title{
Relative sensitivity of two marine bivalves for detection of genotoxic and cytotoxic effects: a field assessment in the Tamar Estuary, South West England
}

\author{
Lorna J. Dallas • Victoria V. Cheung • \\ Andrew S. Fisher • Awadhesh N. Jha
}

Received: 31 January 2012 / Accepted: 23 July 2012

(C) Springer Science+Business Media B.V. 2012

\begin{abstract}
The input of anthropogenic contaminants to the aquatic environment is a major concern for scientists, regulators and the public. This is especially relevant in areas such as the Tamar valley in SW England, which has a legacy of contamination from industrial activity in the nineteenth and twentieth centuries. Following on from previous laboratory validation studies, this study aimed to assess the relationship between genotoxic and cytotoxic responses and heavy metal concentrations in two bivalve species sampled from locations along the Tamar estuary. Adult cockles, Cerastoderma edule, and blue mussels, Mytilus edulis, were sampled from five locations in the Tamar and one reference location on the south Devon coast. Bivalve haemocytes were processed for comet and neutral red retention (NRR) assays to determine potential genotoxic and cytotoxic effects, respectively. Sediment and soft tissue samples were analysed for metal content by inductively coupled plasma mass spectrometry. Sediment concentrations were consistent with the physicochemical nature of the Tamar estuary. A significant
\end{abstract}

L. J. Dallas $\cdot$ V. V. Cheung $\cdot$ A. N. Jha $(\bowtie)$

School of Biological and Biomedical Sciences,

Plymouth University,

Plymouth PL4 8AA, UK

e-mail: a.jha@plymouth.ac.uk

\section{A. S. Fisher}

School of Geography, Earth and Environmental Sciences, Plymouth University,

Plymouth UK PL4 8AA, UK correlation $(P=0.05)$ was found between total metal concentration in sediment and $C$. edule soft tissues, but no such correlation was found for $M$. edulis samples. DNA damage was elevated at the site with highest $\mathrm{Cr}$ concentrations for $M$. edulis and at the site with highest $\mathrm{Ni}$ and $\mathrm{Pb}$ concentrations for $C$. edule. Analysis of NRR revealed a slight increase in retention time at one site, in contrast to comet data. We conclude that the comet assay is a reliable indicator of genotoxic damage in the field for both $M$. edulis and C. edule and discuss reasons for the apparent discrepancy with NRR.

Keywords Bivalve molluscs · Tamar estuary · Metals · Biomarkers · Comet assay $\cdot$ Neutral red retention

\section{Introduction}

Anthropogenic inputs to the environment represent a growing concern for governments, policy makers and the public, particularly in light of increasing global industrialisation and human population growth (Moore et al. 2004; Jha 2004). The marine environment (including estuaries) is often the ultimate recipient of discharged contaminants, and thus identifying and quantifying the potential risks to exposed aquatic biota and human health has become a key challenge for ecotoxicologists, environmental managers and regulatory agencies (Moore et al. 2004). In addition to quantifying levels of contamination with chemical and 
water monitoring programmes, sub-lethal biological responses or biomarker studies on key 'sentinel' or 'bioindicator' species are also essential for environmental risk assessment and protection (Moore et al. 2004; Lyons et al. 2010). In recent years, emphasis on the ecological impact of contaminants has increased. For example, the European Union water framework directive (Directive 2000/60/EC) emphasises the need for ecological quality of the hydrosphere, in particular, focusing on those contaminants which are carcinogenic, mutagenic or show reproductive toxicity (Borja et al. 2004; Fuerhacker 2009). In order to assess these effects, it is important to assess the sub-lethal effects in native biota inhabiting potentially different contaminated sites.

It is generally realised that applications of sublethal biological responses in native organisms have been implemented in only a few selected organisms (Jha 2008). It is often seen that, at contaminated sites, these species are either absent or, if present, their responses might not be indicative of other species in the community (Cheung et al. 2006; Jha 2008). Marine bivalves, such as the blue mussel (Mytilus edulis), are commonly used as bioindicator species in ecotoxicological investigations. Their sessile, filter-feeding mode of life and ease of maintenance in the laboratory make bivalves ideal test species. It is, however, important to bear in mind that sediment is the ultimate depository of contaminants, and as intertidal species, they might not represent the actual biological impact of contaminants on the biota. Many factors have an impact on the biological response to contaminants, including trophic position, feeding methods and habitat; therefore it is imperative to extend the choice of available sentinel species. The fact that bivalves are generally abundant, geographically widespread and display a variety of biological responses when stressed makes them appropriate model organisms in a range of exposure scenarios. In this context, the common cockle, Cerastoderma edule, a sediment-dwelling bivalve that is widely distributed from north-east Norway to West Africa is a potentially useful sentinel species. In contrast to M. edulis, it is mobile and does not attach to the substrata with byssus threads. Despite its characteristics, there have been a limited number of attempts to explore the usefulness of this species for environmental monitoring purposes (Cheung et al. 2006; Lobo et al. 2010; Jung et al. 2006).

The Tamar estuary is a tidal estuary in the southwest of the UK, extending approximately $22 \mathrm{~km}$ landwards from Plymouth Sound, where it meets the sea (Environment Agency 1996). Five rivers (the Tamar, Tavy, Lynher, Plym and Tiddy) run into the Tamar estuary, which then empties into Plymouth Sound (Environment Agency 1996). The Tamar valley is highly mineralised and has been mined (e.g. for $\mathrm{Sn}$, $\mathrm{Cu}, \mathrm{Pb}, \mathrm{Ag}$ and $\mathrm{Zn}$ ) for the last millennium. In the nineteenth century, mining activities were particularly intensive, and the area was the world's largest source of arsenic and copper (Shaw and Moore 2011). In addition to mining, industrial influences on the Tamar estuary include various marinas, the city of Plymouth (with 250,000 inhabitants) and the Devonport Royal Dockyard, where submarine refits are undertaken for the Royal Navy and radioactive waste is discharged. Nutrient enrichment occurs within the upper Tamar estuary mainly from agricultural run-off and sewage discharge (Langston et al. 2003). Chemical data from the Tamar estuary area indicate that, compared with many other estuaries around the British coast, the area contains elevated levels of heavy metals and radionuclides in sediments (Lindsay and Bell 1997) and polycyclic aromatic hydrocarbons both in seawater (Law et al. 1997) and in sediments (Woodhead et al. 1999). In addition, as a result of the PREDICT workshop (Shaw and Moore 2011), ecotoxicological effects of contamination on bivalves in the Tamar estuary have been investigated (Bignell et al. 2011; Money et al. 2011; Shaw et al. 2011). The Tamar estuary is designated as 'An Area of Outstanding Natural Beauty', and two Tamar Valley estuaries have been designated as Sites of Special Scientific Interest (Langston et al. 2003). Despite the ecological significance of this area and the historical and present input of anthropogenic contaminants, there is currently limited published work on biological responses in native biota. In particular, there is little work that compares sublethal toxic responses in different marine species inhabiting the Tamar estuary.

Genotoxic and cytotoxic biomarkers are sensitive sub-lethal indicators of potential environmental toxicity at genetic and cellular levels. In particular, single-cell gel electrophoresis or the Comet assay is a reliable and widely used method for the detection of single- and double-strand DNA breaks at the level of the individual cell. The assay has been implemented in several laboratory and field studies (Jha 2008; Canty et al. 2009). In bivalve molluscs, this assay has been applied to different cell types, including haemocytes 
(Jha 2008; Canty et al. 2009). Furthermore, it is also well established that the genotoxic potency of contaminants or chemicals is closely related to their toxicity at cellular level (i.e. cytotoxicity) for many endpoints (Jha et al. 2000). Cytotoxicity in the haemocytes of bivalve molluscs has also been extensively studied using neutral red retention (NRR) assay developed by Lowe et al. (1995). This assay has been recommended by the International Council for the Exploration of Sea (Moore and Lowe 2004) and has been used in different international monitoring programmes (Moore et al. 2004). Previously, we have compared the relative sensitivity of $M$. edulis and $C$. edule haemocytes for induction of DNA damage using the Comet assay under laboratory conditions and found that haemocytes from $C$. edule are more sensitive (Cheung et al. 2006). In addition, we have also implemented NRR assay in mussels collected from contaminated sites (Cheung et al. 1998). Given our experience with these assays, the goal of this study was to implement them in the field to assess the impact of contaminants on different biota and to evaluate their relative sensitivity.

Against the backdrop of above information, the present study aimed to (1) use the Comet and NRR assays to investigate relative genotoxic and cytotoxic responses in $M$. edulis and $C$. edule collected from various sites along the Tamar estuary and (2) determine if any correlation existed between the biomarker responses and levels of metallic contamination present in the organisms, their environment and the ecological niche they inhabit.

\section{Materials and method}

\section{Sampling sites}

The field sampling for the current investigation was carried out between September and October 2001. Six sampling stations were selected from the Tamar estuary as illustrated in Fig. 1. Site selection was based upon ease of collection for biological and sediment samples in addition to relative location along the estuary. Site 1 was situated at Bantham (Ordnance Survey grid reference: SX 665 438) on the Avon estuary. Relatively little contamination occurs within the vicinity of this site, and an oyster farm is located a few kilometres away-where bivalve molluscs are cultured and farmed for human consumption. This location was therefore considered to be relatively clean and was used as a reference site. Site 2 was located on the shore close to the Torpoint vehicle and passenger ferry terminal (west side of the estuary; SX 442 551). With the exception of the reference site (Bantham), this site was the furthest south and the closest to the sea. Site 3 was located approximately $2 \mathrm{~km}$ north-west of Torpoint close to a jetty at Cove Head, Wilcove (SX 434 567). This site was located approximately opposite to the Devonport Royal Dockyard. It was observed that a few small craft were moored at this location. Site 4 was situated at Jupiter Point, at a jetty located on the southern bank of the river Lynher (SX 416 568). It was noted that there were a number of dinghies moored at site 4 , which are used for training by the Royal Navy. Site 5 was situated under the Tamar Bridge, close to the marina at Saltash (SX 433 586). Site 6 was situated at Neale Point close to Wearde Quay, where the river Tavy meets the river Tamar (SX 436 612).

\section{Organism sampling}

The presence of the species of interest at each potential sampling station was established in advance of the sample collection. In addition, the ease of access to the stations and the distance from the laboratory was taken into account when selecting the sampling stations, to minimise the transportation time and thus the amount of stress placed upon the animals before tissue sampling. Adult M. edulis (4.2-6.2 cm long) were collected from sub-littoral, rocky outcrops at each sampling site at low tide $(n=12 ; 6$ for biomarker studies and 6 for metal analyses). The organisms were carefully removed from their substrate by cutting the byssus threads and were then transported back to the laboratory in a cool box to minimise thermal stress. In addition to the sampling of $M$. edulis, adult $C$. edule (3.5-4.0 $\mathrm{cm}$ from umbo to valve edge; $n=12 ; 6$ for biomarker studies and 6 for metal analyses) were collected from the sub-littoral, silty sediments at each sampling site at low tide. The animals were then transported back to the laboratory in a cool box containing damp tissue paper to maintain humidity. On return to the laboratory, the external shells of the mussel and cockle samples were cleaned of epibionts and sediments. Haemolymph samples were extracted from the sampled animals immediately after they had been 
Fig. 1 a Location of Plymouth within the UK and b location of the sampling stations along the Tamar estuary

\section{(a)}

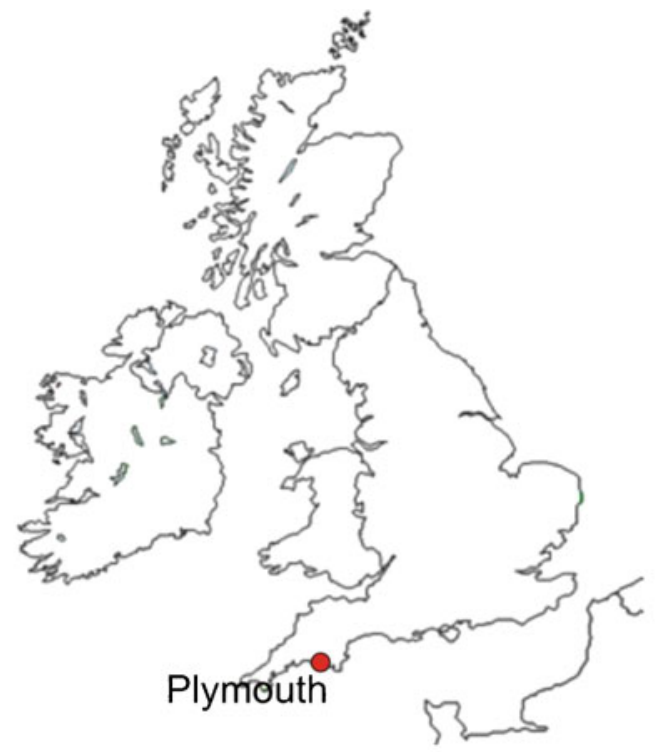

(b)

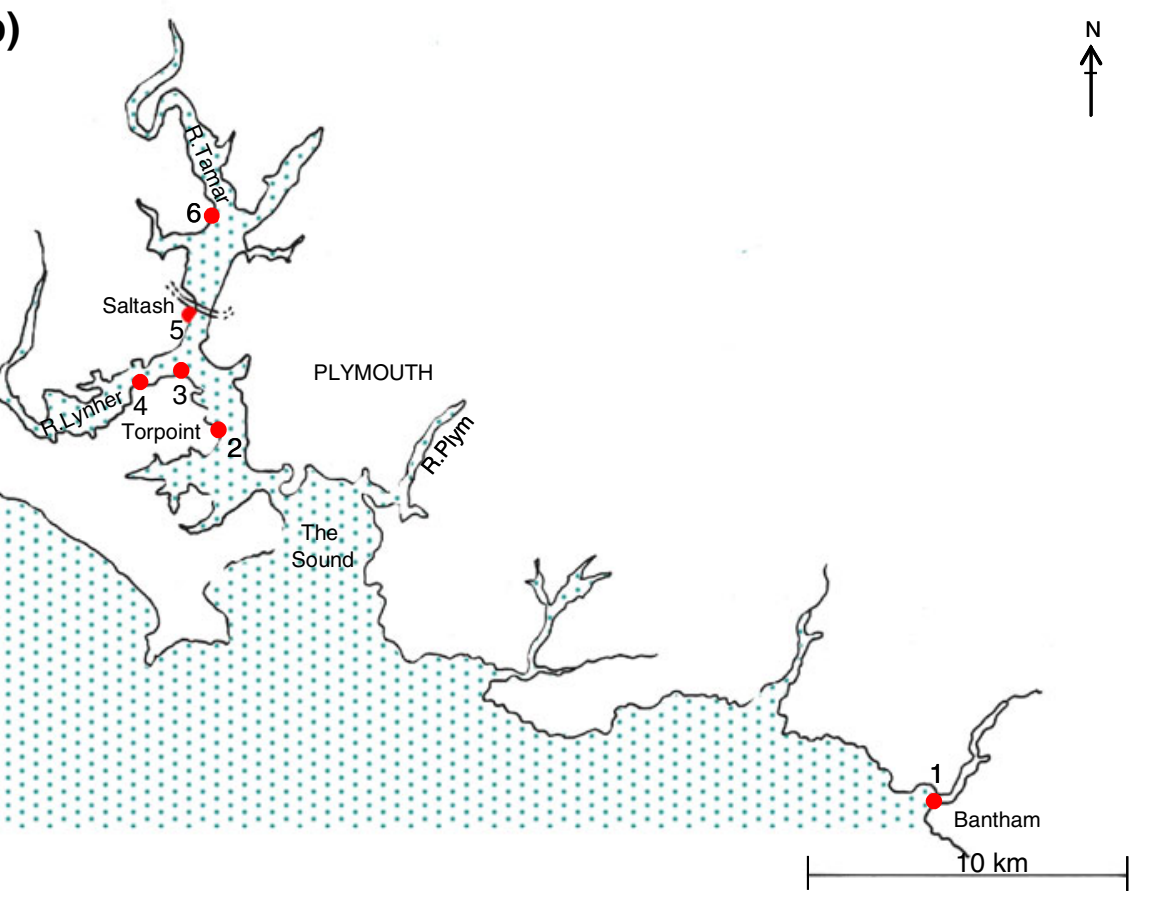

cleaned. The whole animals were then placed into labelled plastic sample bags and stored at $-80^{\circ} \mathrm{C}$ until analysis.

\section{Sediment sampling}

Sediment samples were collected at low tide at the same time and close to where the biological samples were collected. Approximately $5 \mathrm{~kg}$ of the sediment (wet weight) was collected from each sampling site using a small plastic trowel, transported back to the laboratory in labelled plastic sample bags and then stored at $-80^{\circ} \mathrm{C}$ until analysis.

\section{Water sampling}

On the same day that the biological and sediment samples were collected, hydrological parameters $(\mathrm{pH}$, temperature, salinity and dissolved oxygen) were measured in situ at high tide (YSI 550 DO multi- 
incorporated meter; YSI Ltd, Fleet, Hampshire, UK). In addition, approximately $10 \mathrm{~L}$ of water was collected from each site for determination of suspended particulate matter (SPM). Sampling of SPM occurred at high tide, avoiding collection of the water surface microlayer. On return to the laboratory, $1 \mathrm{~L}$ from each seawater sample was filtered through a pre-weighed $0.45-\mu \mathrm{m}$ filter assembled in a Buchner funnel filter unit. Filters were then dried in an oven at $40^{\circ} \mathrm{C}$ for $24 \mathrm{~h}$ and re-weighed. The amount of suspended particulate matter was calculated as milligrams per litre of seawater.

Determination of metal content by inductively coupled plasma mass spectrometry

\section{Sediment preparation}

Preparation of sediments for metal analysis was carried out as per the methods described by Jha et al. (2000). In brief, the sediment samples were placed in an oven at $60^{\circ} \mathrm{C}$ and allowed to dry for 7 days. The dried samples were then ground with a mortar and pestle and sieved through a $180-\mu \mathrm{m}$ nylon mesh. A blank containing only $5 \mathrm{~mL}$ of nitric acid and a certified reference material (LGC 6137, Estuarine Sediment; Laboratory of the Government Chemist, Teddington, UK) were prepared simultaneously in an identical manner.

\section{Preparation of bivalve and reference samples}

Bivalve samples were prepared for inductively coupled plasma mass spectrometry (ICP-MS) analysis as per the following methods. Whole samples were freeze-dried for $24 \mathrm{~h}$; the soft tissues were then extracted from the shell (and the shells discarded), pooled for each site $(n=6)$ and then pulverised using a pestle and mortar. Blanks were prepared, containing only $5 \mathrm{~mL}$ nitric acid and a certified reference material (TORT-2, Lobster hepatopancreas; National Research Council, Canada). Blanks were prepared simultaneously and in an identical manner to samples.

\section{Analysis of sediment and bivalve samples}

From each sample, approximately $0.25 \mathrm{~g}$ of the sieved sediment was placed into acid-washed beakers and
$5 \mathrm{~mL}$ of concentrated nitric acid (Fisher Scientific, Loughborough, UK) added. The samples were covered with a sheet of paper to prevent the ingress of extraneous material and left overnight to pre-digest in a fume cupboard. After pre-digestion, the beakers were placed onto a hotplate and boiled until all the biological material had dissolved. The samples were then allowed to cool, after which they were transferred quantitatively into pre-cleaned 25 -mL-capacity volumetric flasks. Each sample was spiked with a $0.25-\mathrm{mL}$ aliquot of $10 \mu \mathrm{g} \mathrm{mL}^{-1}$ indium solution and diluted to volume with Milli-Q water.

Although the nitric acid extraction is insufficient to dissolve the aluminosilicate material, it is capable of extracting $90 \%$ or more of heavy metals, e.g. copper, cadmium, lead, etc. Other analytes would be less efficiently extracted, such as arsenic and chromium, although efficiency is often greater than $50 \%$. All the dissolved sediment and biological samples were analysed for $\mathrm{Cr}, \mathrm{Mn}, \mathrm{Fe}, \mathrm{Co}, \mathrm{Ni}, \mathrm{Cu}, \mathrm{Zn}, \mathrm{As}, \mathrm{Se}, \mathrm{Cd}, \mathrm{Hg}$ and $\mathrm{Pb}$ using the semi-quantitative analysis software of an ICP-MS instrument (PlasmaQuad PQ2+ Turbo, VG Elemental, Winsford, Cheshire, UK). The results of the certified materials (run in parallel) were used to validate the analyses of the biological and sediment samples. Similar calculations were made for most of the elements detected with the exceptions of $\mathrm{Al}, \mathrm{Ca}$, $\mathrm{Fe}, \mathrm{Mg}$ and $\mathrm{Na}$ in the sediment samples, since for these analytes, the concentration was so high that the linear calibration range of the ICP-MS instrument did not extend that far.

\section{Determination of biomarker responses}

All chemicals were supplied by Sigma-Aldrich Ltd, Gillingham, Dorset, UK, unless otherwise specified.

\section{Sampling of haemolymph}

From each individual of both species, $0.20 \mathrm{~mL}$ of haemolymph was extracted from the posterior adductor muscle via a 21-gauge hypodermic needle into a 0.50 -mL syringe pre-filled with $0.20 \mathrm{~mL}$ physiological saline (20 mM HEPES, $435 \mathrm{mM} \mathrm{NaCl}, 100 \mathrm{mM}$ $\mathrm{MgSO}_{4}, 10 \mathrm{mM} \mathrm{KCl}, 10 \mathrm{mM} \mathrm{CaCl}_{2}, \mathrm{pH}=7.36$ ). Each sample was transferred into siliconised microcentrifuge tubes $(2 \mathrm{~mL})$ and held on ice to minimise cellular stress. 
Single cell gel electrophoresis or the Comet assay

Following cell viability assessment using Eosin Y (samples showed viability $>90 \%$; data not included), the Comet assay was carried out according to the methods of Cheung et al. (2006). Briefly, $100 \mu \mathrm{L}$ of haemolymph was transferred to a siliconised Eppendorf tube and centrifuged for $2 \mathrm{~min}$ at $200 \times \mathrm{g}$. The supernatant was discarded and replaced with $200 \mu \mathrm{L}$ of $0.5 \%$ lowmelting-point agarose (LMPA) held at $40{ }^{\circ} \mathrm{C}$. After gentle mixing, an $85-\mu \mathrm{L}$ aliquot was applied to a microscope slide pre-coated with $1.5 \%$ normal melting point agarose and was immediately topped with a coverglass. This was repeated with a further $85-\mu \mathrm{L}$ aliquot to create a replicate microgel on the same slide. Slides were then placed on ice for approximately $10 \mathrm{~min}$, to allow the LMPA to set. The coverglasses were gently removed and the slides placed in lysis solution $(2.5 \mathrm{M} \mathrm{NaCl}$, $100 \mathrm{mM}$ EDTA, $10 \mathrm{mM}$ Tris base, $1 \%$ sodium sarconisate, $1 \%$ Triton X-100, $10 \%$ DMSO; adjusted to $\mathrm{pH} 10$ by dropwise addition of $10 \mathrm{M} \mathrm{NaOH}$ ) for $1 \mathrm{~h}$ at $4{ }^{\circ} \mathrm{C}$. After lysis, slides were rinsed with distilled water and transferred to the electrophoresis chamber containing electrophoresis buffer $(1 \mathrm{~N} \mathrm{NaOH})$ at room temperature for $20 \mathrm{~min}$ to allow DNA to unwind. After the unwinding period, electrophoresis was carried out for $30 \mathrm{~min}(15 \mathrm{~V}, 320 \mathrm{~mA})$. Slides were then rinsed with distilled water and immersed in neutralisation buffer (0.4 M Tris, adjusted to $\mathrm{pH} 7$ with $\mathrm{HCl}$ ) for $5 \mathrm{~min}$. Following staining with ethidium bromide $(40 \mu \mathrm{L}$ of $20 \mu \mathrm{g} / \mathrm{mL}$ per microgel), 100 cells per sample (50 per replicate microgel) were scored using an epifluorescence microscope (Leica Microsystems Ltd, Milton Keynes, Buckinghamshire, UK) and Komet 5.0 imageanalysis system (Kinetic Imaging, Liverpool, UK). The comet parameters, tail length and tail moment (tail length $\times \%$ tail DNA $/ 100$ ) were used for data analyses, as these were found to be most sensitive in an earlier study (Cheung et al. 2006).

\section{Neutral red retention (NRR) assay}

The NRR assay was used to determine cytotoxicity in the haemocyte samples as described elsewhere in detail (Lowe 1988; Lowe et al. 1995; Moore and Lowe 2004; Cheung et al. 1998; Wedderburn et al. 1998). Briefly, a stock solution of neutral red was prepared by dissolving $20 \mathrm{mg}$ of dye in $1 \mathrm{~mL}$ DMSO. The working solution was made by adding $5 \mu \mathrm{L}$ of stock to $995 \mu \mathrm{L}$ of physiological saline (Lowe et al. 1995). Of the haemolymph samples collected from each individual, a $40-\mu \mathrm{L}$ aliquot was used for the NRR assay. Haemolymph was added to a microscope slide pre-coated with $10 \%$ poly-L-lysine (to aid cellular adhesion). Slides were incubated in the dark at $20{ }^{\circ} \mathrm{C}$ for $30 \mathrm{~min}$ to allow cells to attach. After removal of the excess cell suspension, $40 \mu \mathrm{L}$ of neutral red working solution was added, and the slide was left to incubate for a further $15 \mathrm{~min}$ (Lowe 1988). Slides were examined under a light microscope (Leica DMR) every $15 \mathrm{~min}$ for the first hour and thereafter every $30 \mathrm{~min}$ (Lowe and Pipe 1994). The time at which $\geq 50 \%$ of the cells showed leakage of the dye from the lysosomal compartment into the cytoplasm was recorded, and observation of that slide was terminated at that point (Lowe 1988; Lowe et al. 1995; Moore and Lowe 2004; Cheung et al. 1998; Wedderburn et al. 1998).

Statistical analyses

Statistical analyses were carried out using the statistical packages Statgraphics Plus Version 4.0, Minitab 15.1 and Microsoft Excel 2007. All data were tested for normality and the appropriate parametric or nonparametric tests used. Pearson's correlation coefficient $(R)$ was calculated for the relationship between total metal content in sediment and in bivalve soft tissue. For the comet assay, all data were nonparametric, and consequently, the Kruskal-Wallis test was applied. However, data for comet tail length in $C$. edule could be normalised by log-transformation, and a one-way ANOVA was performed on transformed data. For the NRR assay, data for $M$. edulis were normally distributed, whereas data for $C$. edule were non-normal. $C$. edule data were normalised by logtransformation, and subsequently, all NRR data were analysed with one-way ANOVAs. Significance was set at $P<0.05$ for all tests.

\section{Results and discussion}

\section{Hydrological parameters}

Table 1 presents the hydrological data from each sampling site. The $\mathrm{pH}$ of the water was slightly lower at the sites that were located further upstream. This may have been due to a combination of the relatively high levels of contamination and lower amounts of circulation and dilution at these sites. There was minimal 
Table 1 Hydrological measurements at sites along the Tamar estuary

\begin{tabular}{llllll}
\hline Site & $\mathrm{pH}$ & $\begin{array}{l}\text { Temperature } \\
\left({ }^{\circ} \mathrm{C}\right)\end{array}$ & Salinity & $\begin{array}{l}\text { Dissolved } \\
\text { oxygen }\left(\mathrm{mg} \mathrm{L}^{-1}\right)\end{array}$ & $\begin{array}{l}\mathrm{SPM} \\
\left(\mathrm{mg} \mathrm{L}^{-1}\right)\end{array}$ \\
\hline 1 & 8.02 & 16.4 & 35.1 & 6.93 & 31.3 \\
2 & 7.88 & 17 & 34.8 & 5.37 & 35.2 \\
3 & 7.83 & 16.2 & 33.5 & 6.46 & 29.8 \\
4 & 7.81 & 17 & 33.3 & 6.4 & 14.9 \\
5 & 7.8 & 17.9 & 34.1 & 7.83 & 23.8 \\
6 & 7.76 & 17.4 & 33.4 & 6.2 & 21.5 \\
\hline
\end{tabular}

temperature variation between the sites, with the small difference (maximum difference of $1.2{ }^{\circ} \mathrm{C}$ ) probably attributable to differences in shading from foliage. Salinity ranged from 33.3 to 35.1 and increased towards the open sea, as expected. There was no clear trend in either dissolved oxygen or SPM levels; however, it was noted that the highest level of SPM (35.2 $\mathrm{mg} \mathrm{L}^{-1}$ ) was measured in water collected from site 2 (Torpoint), which also had the lowest dissolved oxygen levels, suggesting that the aerobic breakdown of organic matter present in the SPM was depressing local oxygen levels.

Heavy metal analyses

Analysis of certified reference materials indicated that the analytical techniques used were accurate to within $10 \%$ of certified values.

\section{Sediments}

Individual concentrations for each heavy metal measured are presented in Table 2. Figure 2a presents the total concentration of heavy metals measured in the sediments collected from the six sampling sites. It should be noted that measurements of the certified sediment material indicated that there was a significant underestimation of the measurements for $\mathrm{Fe}$ and $\mathrm{Hg}$. The data collected for these two elements are therefore deemed to be inaccurate and have not been included in total heavy metal calculations. Sediment from site 1 had the lowest total metal concentration and was found to have the lowest concentrations of all the metals measured, except Fe. Total metal concentration was highest at site 5 (Fig. 2a); however, site 6 had the most number of metals at their highest concentrations

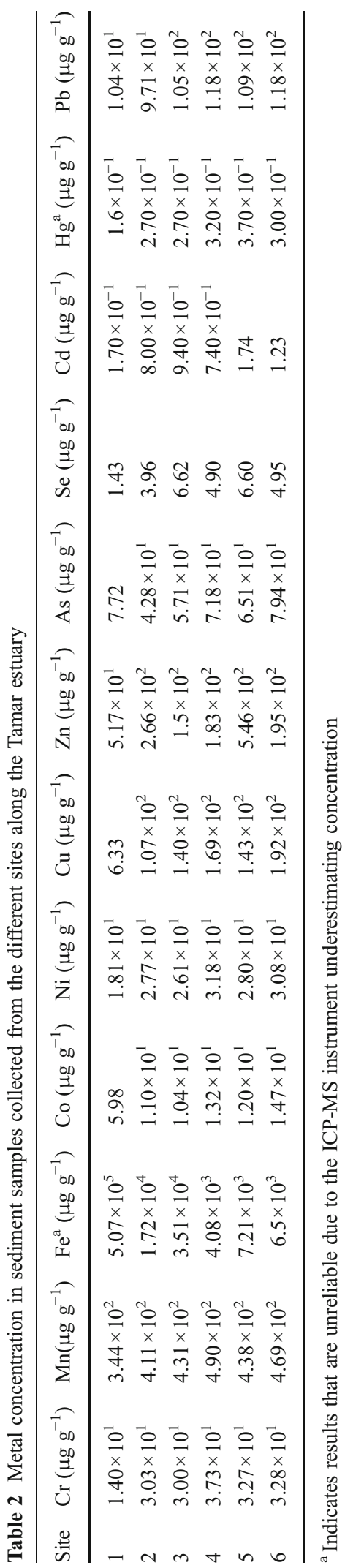


Fig. 2 a Total metal concentration (excluding $\mathrm{Fe}$ and $\mathrm{Hg}$ ) at each site for sediment (dotted bar) and soft tissue of M. edulis (black bar) and C. edule (grey bar). b Correlation between total metal concentration in sediment and that in soft tissues of M. edulis (filled diamonds, solid line) and $C$. edule (open circles, dashed line)
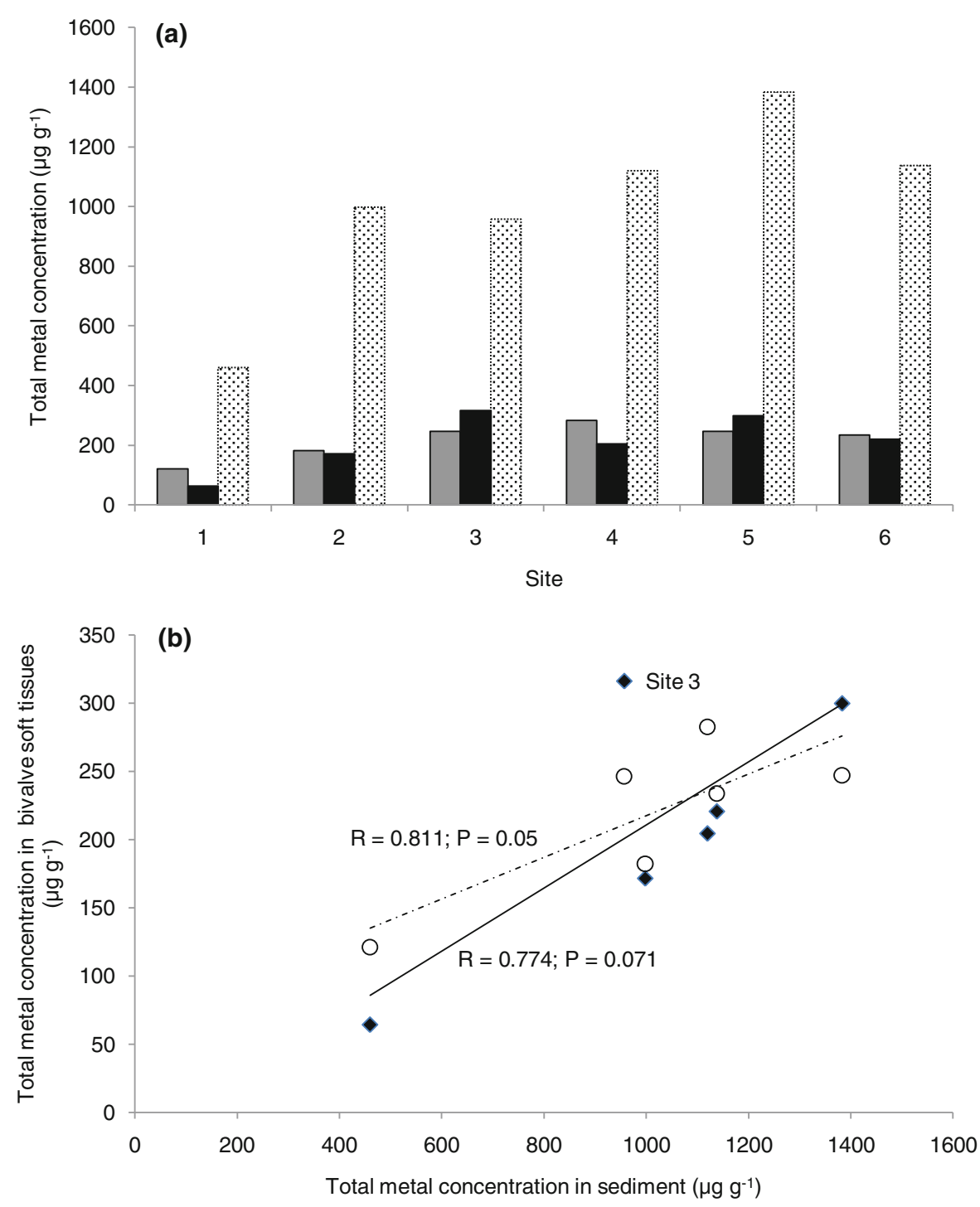

(Co, Cu, As and Pb; Table 2). Site 4 had the highest concentrations of $\mathrm{Cr}, \mathrm{Mn}$ and $\mathrm{Ni}$, whereas site 5 had the highest concentrations of $\mathrm{Zn}$ and $\mathrm{Cd}$. The results for sites 4, 5 and 6 are consistent with these sites being furthest away from the sea, where water exchange would be the lowest due to the physico-chemical nature of the Tamar estuary.

\section{Biological material}

The individual metal concentrations for M. edulis and $C$. edule are presented in Tables 3 and 4, respectively. Figure 2a illustrates total metal concentrations for both organisms. For consistency with sediment data, soft tissue total metal concentrations do not include Fe or
$\mathrm{Hg}$. Both species had the lowest total metal concentration and the lowest concentrations of $\mathrm{Mn}, \mathrm{Fe}, \mathrm{Co}$, $\mathrm{Ni}, \mathrm{Zn}$, Se and $\mathrm{Pb}$ at the reference site (Fig. 2a; Tables 3 and 4). Cockle samples, however, had the highest concentration of $\mathrm{Cd}$ at site 1 (Table 4). Of all the metals measured, Fe concentrations were the highest for both species, with the mean soft tissue concentration across all sites $417 \pm 182 \mu \mathrm{g} \mathrm{g}^{-1}$ for mussels and $1,211 \pm 210 \mu \mathrm{g} \mathrm{g}^{-1}$ for cockles. $\mathrm{Hg}$ concentrations were the lowest with $0.11 \pm 0.09$ and $0.11 \pm 0.15 \mu \mathrm{g} \mathrm{g}^{-1}$ for mussels and cockles, respectively. Highest total metal concentrations in soft tissues were at site 3 for mussels and site 4 for cockles (Fig. 2a). In terms of the number of metals at their highest concentration, site 5 was most contaminated for both species. Mussels from 


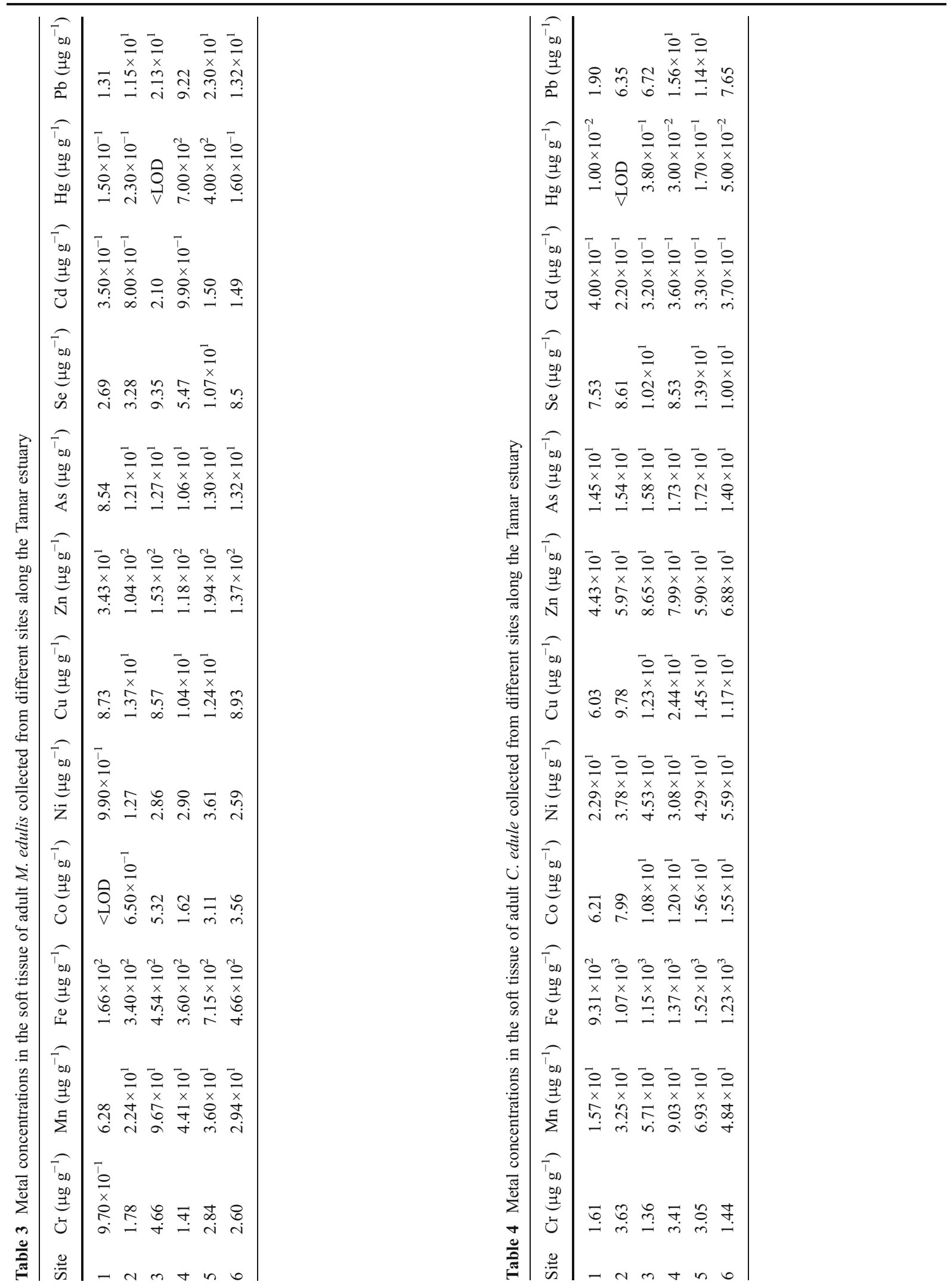


site 5 showed the highest levels of $\mathrm{Fe}, \mathrm{Ni}, \mathrm{Zn}$, Se and $\mathrm{Pb}$. Consistent with the mussel results, cockles from site 5 also had the highest levels of $\mathrm{Fe}$ and Se but also had the highest levels of $\mathrm{Co}$ and $\mathrm{Cu}$. Mussel soft tissues also showed contamination from numerous heavy metals at site 3 , where they exhibited the highest concentrations of $\mathrm{Cr}, \mathrm{Mn}, \mathrm{Co}$ and $\mathrm{Cd}$. As in mussel samples, site 3 also yielded cockle samples with the highest concentrations of several metals, although this was for different elements ( $\mathrm{Zn}$, As and $\mathrm{Hg}$ ). This is inconsistent with the results from sediment analysis, where this site had the highest concentration of Se only. In addition, cockles from this site also contained the highest levels of $\mathrm{Cu}$, As and $\mathrm{Pb}$. This preferential accumulation of metals suggests different rates of uptake, accumulation, metabolism and excretion in these two bivalve species under natural conditions (Phillips 1977).

When comparing trends in sediment and soft tissue, only two samples were consistent. Both sediment and C. edule samples from site 4 had the highest $\mathrm{Mn}$ concentrations across sampling sites. Similarly, both sediment and $M$. edulis samples at site 5 showed the highest levels of Zn. A statistically significant correlation was found between total metal concentration in sediments and total metal concentration in $C$. edule soft tissues $(P=0.05)$. Despite a similar trend for $M$. edulis soft tissue samples, the correlation was not significant (Fig. 2b).

Biological responses or biomarkers

\section{Comet assay}

Due to the constraints imposed by the quantity of animals that could be collected from each site and the number of samples which could be processed per experimental session, the Comet assay was carried out on six animals per site for each species. There were insufficient $M$. edulis adults within the acceptable size range at Torpoint (site 2) for the Comet assay to be carried out.

Data for DNA damage in haemocytes of M. edulis are presented in Fig. $3 a$ and b. The results for tail length (geometric length of the tail) and tail moment (measured in arbitrary units) showed some inconsistencies, hence they both were included for relative comparison (Fig. 3a and b). Normally, data for different Comet assay parameters generated through commercially available software show the same trends (Kumaravel and Jha 2006), but the way measurements of these parameters are made, optical, and programming variables might also influence and potentially alter the observed pattern (Kumaravel et al. 2009). For tail length, it appears that $M$. edulis sampled from site 3 had significantly less DNA damage than those from the reference site $(P<0.005)$. For tail moment, there was a statistically significant increase in DNA damage at the same site $(P<0.005)$. Both parameters however indicate a significantly increased incidence of DNA damage at site $6(P<0.0001)$. Although tail length has been validated as an appropriate measure of DNA damage in M. edulis in previous studies, it is generally not regarded as a robust parameter for Comet assay analysis (Collins 2004; Kumaravel and Jha 2006). In particular, it increases most dramatically at low levels of damage (Collins 2004), so the very small decrease shown here may be statistically significant but not biologically so. As tail moment incorporates a measure of the fraction of DNA that has migrated from the comet head, it is closer to \% tail DNA, the recommended measure of DNA damage from the Comet assay (Collins 2004; Kumaravel and Jha 2006). The remainder of our analysis will therefore focus on alterations in tail moment.

Total metal concentration in the soft tissues of $M$. edulis was highest at site 3, which also showed genotoxicity; however, the overall pattern is inconsistent as no increase in DNA damage was observed at site 5 . Despite this, an examination of the individual metal concentrations at sites 3 and 6 reveals some possible links between metals and genotoxic effects. Although the highest body burden for a single metal in M. edulis at site 3 was $\mathrm{Fe}$ (as at all sites; Table 3), Fe concentration was highest at site 5 , where there was no significant DNA damage, indicating that perhaps other metals are responsible for this effect. The two metals that were at their highest concentrations in M. edulis soft tissues at site 3 were $\mathrm{Cr}$ and $\mathrm{Mn}$. Cr has previously been found to cause DNA damage in M. edulis at tissue concentrations of $\geq 2.70 \mu \mathrm{g} \mathrm{g}^{-1}$ wet weight after laboratory exposure (Emmanouil et al. 2007). Additionally, Rank et al. (2005) found a significant correlation between chromium concentration and DNA damage (tail moment) in field-sampled M. edulis off the Danish coast. As Mn is an essential metal for most species, including M. edulis (Pipe et al. 1993), and there are currently no reports of Mn causing DNA 
Fig. 3 The level of DNA damage, as measured by the Comet assay, in haemocytes of bivalve molluscs sampled from the Tamar estuary; a tail length in M. edulis haemocytes; b tail moment in M. edulis haemocytes; c tail moment in $C$. edule haemocytes. $*$ denotes a statistically significant difference from the reference site $1(P<0.005)$ (a)

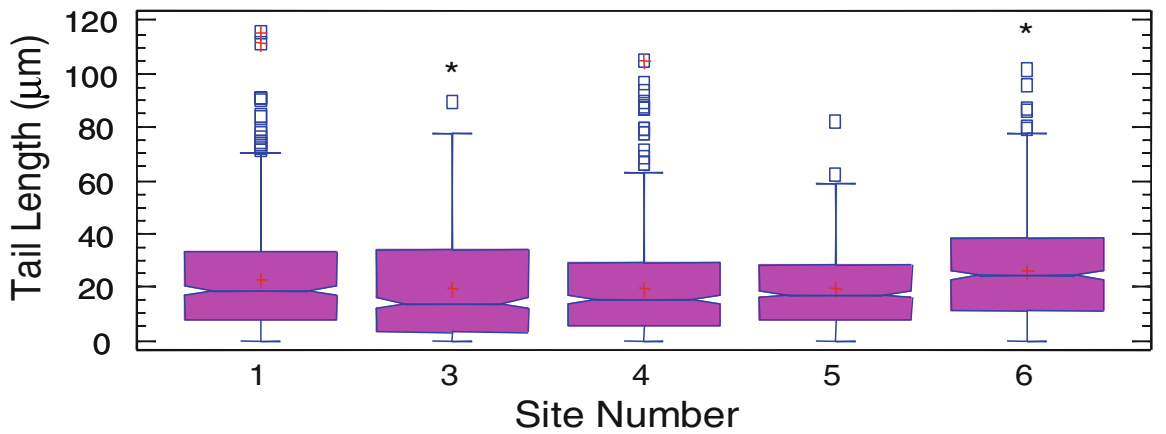

(b)

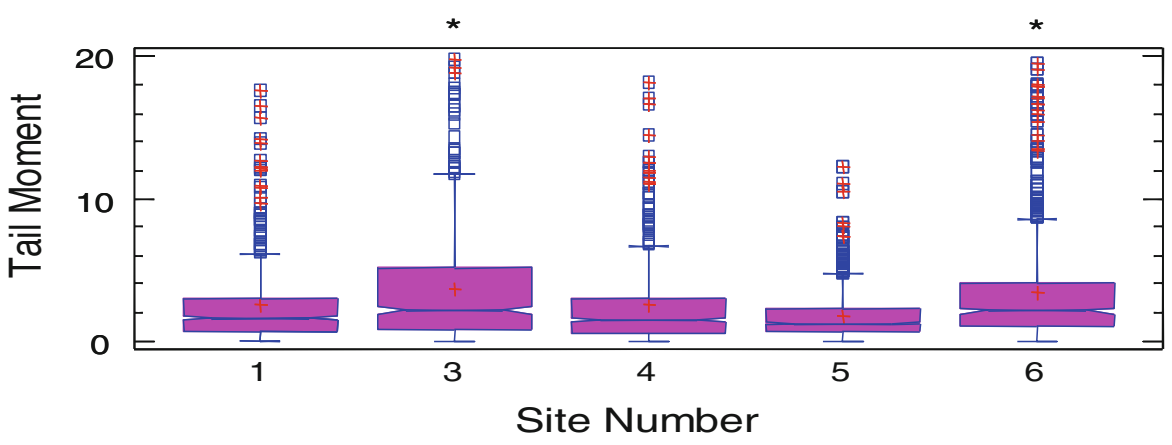

(c)

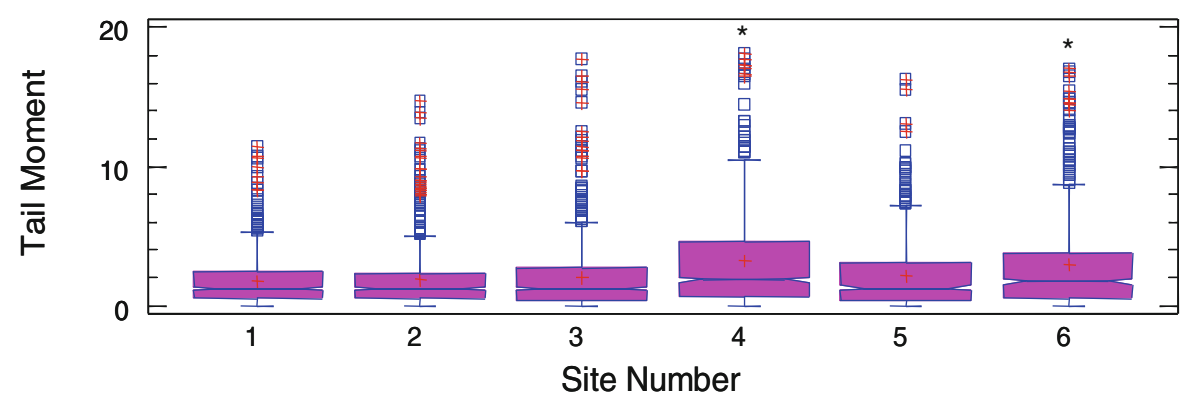

damage in mussels, it is more likely that the damage seen here is caused by $\mathrm{Cr}$, although interactive effects of these two and other metals along with other contaminants could not be ruled out. At site 6 , the potential cause of the elevated DNA damage is not as clear. The concentration of As was the highest of all the sites (13.21 $\mathrm{g} \mathrm{g} \mathrm{g}^{-1}$ ) but was still similar to that at site 5 (13.02 $\mu \mathrm{g} \mathrm{g}^{-1}$ ) where there was no significant DNA damage. Similarly, $\mathrm{Pb}, \mathrm{Ni}, \mathrm{Zn}, \mathrm{Se}$ and $\mathrm{Pb}$ were all found at considerably higher body burdens at this site than at the reference site, but all were higher at site 5, where no significant damage occurred.

The data for tail moment in C. edule haemocytes is presented in Fig. 3c. An increase in the mean tail length of the samples collected from $C$. edule from site 4 compared with the reference site was statistically significant $(P=0.0002)$ in the log-transformed data. However, when the Kruskal-Wallis test was applied to the non-transformed (non-parametric) data, there was not a statistically significant increase when comparing the various sites with the reference site (data not shown). When considering the data for the tail moment, it was found that the level of DNA damage was significantly higher in samples collected from sites 4 and 6 when compared with the reference site $(P<0.005)$.

When the Comet assay data are compared with the concentrations of heavy metals in the sediments and 
the soft tissue of $C$. edule collected from the same sites, there is again no consistent link between total metal concentration in soft tissues and the Comet assay data. Although the highest total metal body burden was found at site 4, which is consistent with increased DNA damage at this site, sites 3 and 5 had higher total metal concentrations than site 6 but did not show correspondingly elevated incidence of genotoxicity. Analysis of individual metal data suggests possible reasons for the genotoxic damage at sites 4 and 6 in particular. Both $\mathrm{Ni}$ and $\mathrm{Pb}$ were present at their highest concentrations in tissues from cockles sampled at sites 4 and 6, respectively. Nickel is a known mammalian carcinogen (Beyersmann and Hartwig 2008) and has been shown to cause DNA damage in another bivalve, Mytilus sp. (Millward et al. 2012). Although $\mathrm{Pb}$ has yet to be shown to be genotoxic in $C$. edule, it has been found to produce elevated levels of DNA damage (as measured by the Comet assay) in human lymphocytes (Anderson et al. 1997). Furthermore, $\mathrm{Pb}$ has been correlated with a reduction in delta-aminolevulinic acid dehydratase activity in field-sampled C. edule (Company et al. 2011), indicating it has the potential to cause toxic effects in this species. A number of previous reports have reported elevated levels of DNA damage (as measured by the Comet or DNA alkaline unwinding assays) after field exposures of indigenous or deployed marine organisms in areas with high levels of organic and metal contaminants (Nacci and Jackim 1989; Nacci et al. 2002; Everaarts 1995; Sasaki et al. 1997; Steinert et al. 1998; Frenzilli et al. 1999, 2001). This is consistent with the results presented here, as the DNA damage responses detected with the Comet assay appear to correlate with the relative heavy metal concentrations in sediments.

\section{Neutral red retention (NRR) assay}

The NRR assay was carried out on six animals from each site, with duplicate slides being prepared from each animal. As with the Comet assay, there were insufficient $M$. edulis adults within the acceptable size range at Torpoint (site 2) for the NRR assay to be carried out. The data showing the mean retention time of neutral red dye in M. edulis haemocytes are presented in Fig. 4a. There was no statistically significant difference between the means of the samples from each of the sites $(P=0.7606)$. Although mussel haemocytes from site 5 appeared to have a lower retention time than the other sites (which would be consistent with the total metal concentration of sediments), this was not found to be statistically significant. With respect to $C$. edule, there was a statistically significant difference between the mean neutral red retention time of the samples collected from the reference site and those collected from site 5 in the log-transformed data ( $P=0.0113$; Fig. 4b). However, this difference was actually an increase in relation to the reference site, indicating that the animals were less stressed at site 5 than at the reference site. This results contrasts with the total metal concentration in sediment, the weak trend for M. edulis and with the body burden data for C. edule. The pattern of NRR across sites was different for both species (Fig. 4a and b), and in general, $M$. edulis haemocytes retained the neutral red for less time than those of $C$. edule. This contradicts the idea that M. edulis has higher immunological vigour than $C$. edule (Wootton et al. 2003).

The NRR assay has been used in a number of field studies to assess cell injury (Lowe 1988; Cheung et al. 1998; Wedderburn et al. 1998). Although the acidic nature of the internal environment of the lysosomal compartment would not be expected to be suitable for metal accumulation, data demonstrate that lysosomes are nonetheless important sites of metal compartmentalisation in the cell (Viarengo 1985). Both $\mathrm{Cu}$ and $\mathrm{Cd}$ have been found to cause detrimental effects on the stability of the lysosomal membrane (Moore et al. 1984). However, not all heavy metal ions cause damaging effects on the lysosomal compartment. Some studies have indicated that $\mathrm{Zn}$ is able to stabilise the lysosomal membranes (Sternlieb and Goldfischer 1976), and stimulatory effects on the lysosomal enzymes have been observed (Webb 1979). This could potentially explain the surprising increase in retention time for site 5 , where body burden data show $\mathrm{Zn}$ present at higher levels than the reference site, although still at lower levels than at site 3 , where it was highest.

In addition to heavy metals, polycyclic aromatic hydrocarbons (PAHs) have been reported to induce destabilisation of the lysosomal compartment, and the NRR assay has been used to identify cytotoxic effects of such pollutants. In a study of mussels located close to the location of the spillage of oil from the Sea Empress tanker, the stability of the lysosomal compartment was found to be inversely correlated with PAH concentration in the mussel tissues (Fernley et al. 2000). It is therefore likely that, in addition to 
Fig. 4 The neutral red retention time of the lysosomal compartment of a $M$. edulis and b $C$. edule haemocytes collected from field sites along the Tamar estuary. Error bars indicate \pm 2 SEM. * denotes a statistically significant difference from the reference site $(P<0.001)$ (a)

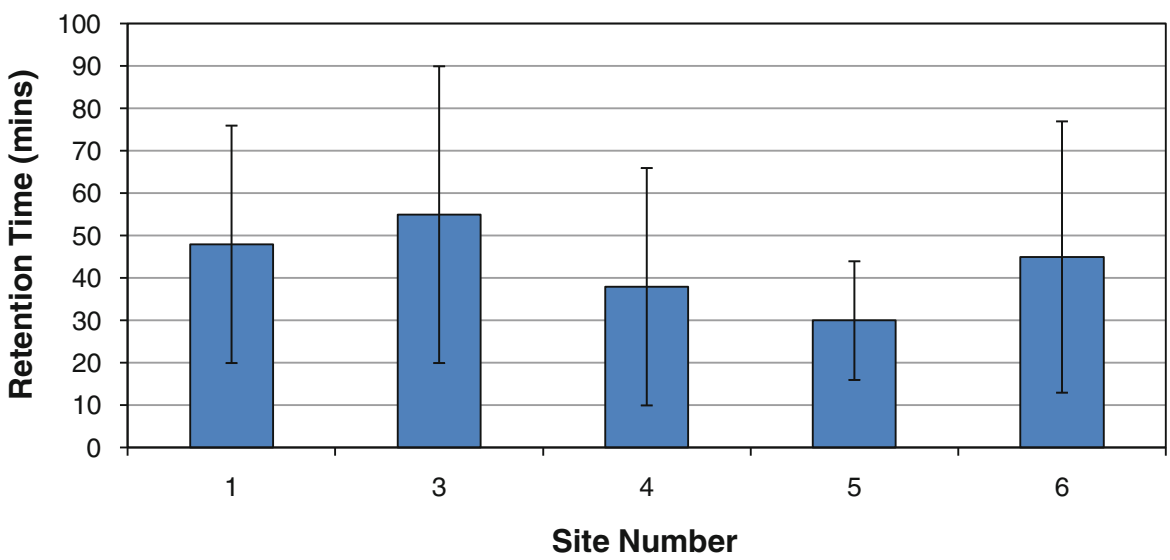

(b)

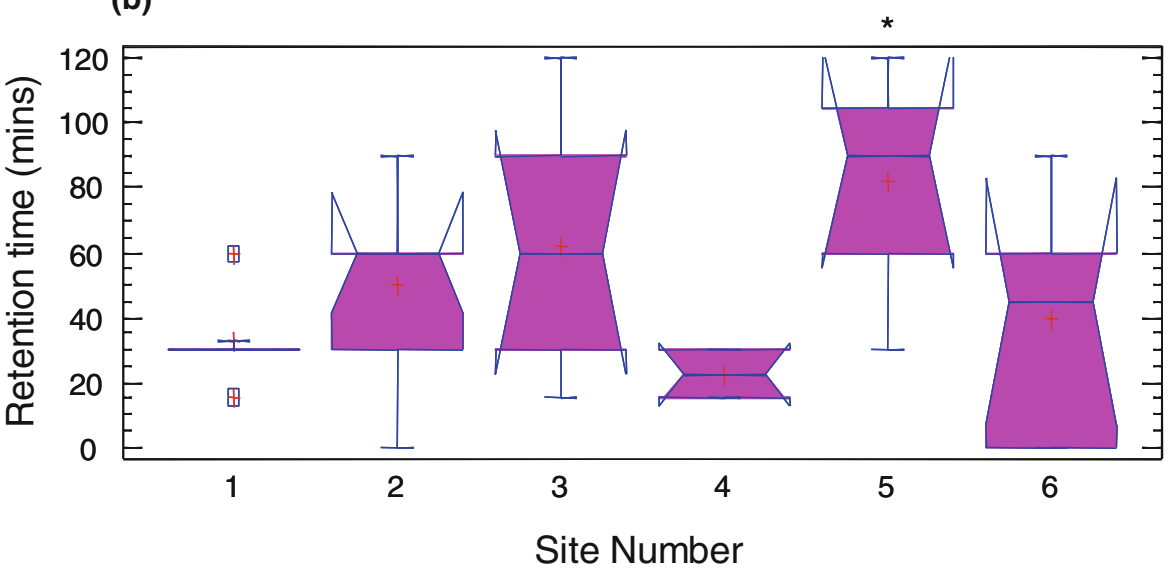

metallic contaminants, other contaminants including PAHs or pesticides present in the environment might influence the biological responses. Metal speciation in natural waters is of high importance and relevance since toxicity, bioavailability, environmental mobility and biogeochemical behaviour are all strongly dependent on the chemical species of metals (Fytianos 2001; Money et al. 2011). Furthermore, the kinetics of the rate of adsorption has a direct effect upon the quantities of contaminants taken up by filter feeders (Liu et al. 1998). In addition, biotic factors, such as the feeding rate, size, sex, maturity and disease state of the test organisms can have pronounced effects on the toxicity of a given substance. For example, Hagger et al. (2010) showed that NRR, feeding rate and cardiac output of $M$. edulis all varied significantly with season. The occurrence of sampling for the current study in September to October, a period when Hagger et al. (2010) report a sharp drop in retention time for the
NRR assay, may have masked any toxic effects caused by differential metal concentrations.

The data presented here do indicate potential relationships between metal pollution in the Tamar estuary and genotoxic effects (particularly with respect to $\mathrm{Cr}$ for $M$. edulis, and $\mathrm{Ni}$ and $\mathrm{Pb}$ for $C$. edule). Despite this, there are several factors that require further discussion and examination. For example, in addition to seasonal variation for the sampling period (i.e. September-October) influencing biological responses (Hagger et al. 2010), identification of individuals and species with high levels of resistance to contaminant effects would assist in answering questions related to either physiological acclimatisation or evolutionary adaptation (Nevo et al. 1986). The Tamar valley lies in a region previously identified as containing both $M$. edulis and the closely related species Mytilus galloprovincialis, in addition to large numbers of hybrids (Hilbish et al. 2002). Although individual mussels 
collected in the present study were preliminarily identified as M. edulis, the morphological distinction between these species is unclear. Robust genetic markers to classify species would have provided a useful crossreference, to ensure that all sampled mussels were correctly identified, or to correlate any discrepancies in the data with species. It is also crucial to note that both the Comet and NRR assays were carried out on bivalve haemocytes, but metal analysis was on soft tissues. This discrepancy may account for the apparent inconsistencies between total metal concentration in the soft tissues and genotoxic/cytotoxic responses.

\section{Conclusion}

There have been suggestions that ecotoxicological studies are problematic in natural environments due to many inherent limitations and genetic variability within natural populations as well as individuals. This inherent variability makes the selection of suitable "control" or "reference" populations very difficult (Hasspieler et al. 1995). Human and fish cell lines have been suggested as alternatives to the use of aquatic organisms in vivo for the screening and testing of water quality (Papis et al. 2011; Baron et al. 2012). Such studies however do not take into consideration the biotic (e.g. adaptation, inter/intra-species effects) or abiotic (e.g. temperature, salinity) factors that can affect indigenous populations in conjunction with chemical contamination. Additionally, aquatic invertebrates cell-lines are less readily available than the vertebrate equivalents (Dixon et al. 2002), and the use of tissues from vertebrates might overlook effects on this ecologically important group. Furthermore, whilst there have been some studies to determine relative sensitivity of ecologically relevant invertebrates following exposure to contaminants under laboratory conditions (e.g. Canty et al. 2009), there has been limited, concurrent studies pertaining to relative sensitivity of species for sub-lethal toxic effects under natural conditions. In this context, the current study has demonstrated that biomarker responses previously identified and implemented in laboratory studies can be applied to indigenous populations of M. edulis and C. edule collected from the field. In particular, the results of the Comet assay appeared to correlate with high concentrations of heavy metals within the soft tissues. Measures should however be taken to further reduce confounding physical and biotic factors in order to fully understand the causes of the biological responses observed.

Acknowledgment Partial financial support from European Regional Development Fund, INTERREG IVA (grant no. 4059) is acknowledged.

\section{References}

Anderson, D., Dobrzyńska, M. M., \& Basaran, N. (1997). Effect of various genotoxins and reproductive toxins in human lymphocytes and sperm in the Comet assay. Teratogenesis Carcinogenesis and Mutagenesis, 17(1), 29-43.

Baron, M. G., Purcell, W. M., Jackson, S. K., Owen, S. F., \& Jha, A. N. (2012). Towards a more representative in vitro method for fish ecotoxicology: Morphological and biochemical characterisation of three-dimensional spheroidal hepatocytes. Ecotoxicology. doi:10.1007/s10646-0120965-5.

Beyersmann, D., \& Hartwig, A. (2008). Carcinogenic metal compounds: Recent insight into molecular and cellular mechanisms. Archives of Toxicology, 82, 493-512.

Bignell, J. P., Stentiford, G. D., Taylor, N. G. H., \& Lyons, B. P. (2011). Histopathology of mussels (Mytilus sp.) from the Tamar estuary, UK. Marine Environmental Research, 72 (1-2), 25-32. doi:10.1016/j.marenvres.2011.05.004.

Borja, A., Valencia, V., Franco, J., Muxika, I., Bald, J., Belzunce, M. J., et al. (2004). The water framework directive: Water alone, or in association with sediment and biota, in determining quality standards? [doi: DOI: 10.1016/j.marpolbul.2004.04.008]. Marine Pollution Bulletin, 49, 8-11.

Canty, M. N., Hutchinson, T. H., Brown, R. J., Jones, M. B., \& Jha, A. N. (2009). Linking genotoxic responses with cytotoxic and behavioural or physiological consequences: Differential sensitivity of echinoderms (Asterias rubens) and marine molluscs (Mytilus edulis). Aquatic Toxicology, 94, 68-76.

Cheung, V. V., Wedderburn, R. J., \& Depledge, M. H. (1998). Molluscan lysosomal responses as a diagnostic tool for the detection of a pollution gradient in Tolo Harbour, Hong Kong. Marine Environmental Research, 46(1-5), 237-241. doi:10.1016/s0141-1136(97)00104-9.

Cheung, V. V., Depledge, M. H., \& Jha, A. N. (2006). An evaluation of the relative sensitivity of two marine bivalve mollusc species using the Comet assay. [Proceedings Paper]. Marine Environmental Research, 62, S301-S305, doi:10.1016/j.marenvres.2006.04.053.

Collins, A. R. (2004). The comet assay for DNA damage and repair-Principles, applications, and limitations. Molecular Biotechnology, 26(3), 249-261.

Company, R., Serafim, A., Lopes, B., Cravo, A., Kalman, J., Riba, I., et al. (2011). Source and impact of lead contamination on delta-aminolevulinic acid dehydratase activity in several marine bivalve species along the Gulf of Cadiz. [Article]. Aquatic Toxicology, 101(1), 146-154. doi:10.1016/j.aquatox.2010.09.012. 
Dixon, D. R., Pruski, A. M., Dixon, L. R. J., \& Jha, A. N. (2002). Marine invertebrate eco-genotoxicology: A methodological overview. Mutagenesis, 17(6), 495-507. doi:10.1093/mutage/17.6.495.

Emmanouil, C., Sheehan, T. M. T., \& Chipman, J. K. (2007). Macromolecule oxidation and DNA repair in mussel (Mytilus edulis L.) gill following exposure to $\mathrm{Cd}$ and $\mathrm{Cr}(\mathrm{VI})$. Aquatic Toxicology, 82(1), 27-35. doi:10.1016/ j.aquatox.2007.01.009.

Environment Agency (1996). Tamar estuary and tributaries: Consultation report. (pp. 7). London, UK: Environment Agency.

Everaarts, J. M. (1995). DNA integrity as a biomarker of marine pollution: Strand breaks in sea star (Asterias rubens) and dab (Limand limanda). Marine Pollution Bulletin, 31(4), 431-438.

Fernley, P. W., Moore, M. N., Lowe, D. M., Donkin, P., \& Evans, S. (2000). Impact of the Sea Empress oil spill on lysosomal stability in mussel blood cells. Marine Environmental Research, 50(1-5), 451-455. doi:10.1016/s01411136(00)00118-5.

Frenzilli, G., Scarcelli, V., Taddei, F., \& Nigro, M. (1999). Adaptation of SCGE for monitoring marine ecosystems. Neoplasma, 46(Suppl), 6-7.

Frenzilli, G., Nigro, M., Scarcelli, V., Gorbi, S., \& Regoli, F. (2001). DNA integrity and total oxyradical scavenging capacity in the Mediterranean mussel, Mytilus galloprovincialis: A field study in a highly eutrophicasted coastal lagoon. Aquatic Toxicology, 53, 19-32.

Fuerhacker, M. (2009). EU water framework directive and stockholm convention. Environmental Science and Pollution Research, 16, 92-97.

Fytianos, K. (2001). Speciation analysis of heavy metals in natural waters: A review. Journal of AOAC International, 84(6), 1763-1769.

Hagger, J. A., Lowe, D., Dissanayake, A., Jones, M. B., \& Galloway, T. S. (2010). The influence of seasonality on biomarker responses in Mytilus edulis. Ecotoxicology, 19 (5), 953-962. doi:10.1007/s10646-010-0477-0.

Hasspieler, B. M., Alipour, M., Ali, F. N., Haffner, G. D., \& Adeli, K. (1995). Assessment of cyto- and genotoxicity of environmental samples. In F. M. Butterworth, L. D. Corkum, \& J. Guzmán-Rincón (Eds.), Biomonitors and biomarkers as indicators of environmental change: A handbook (pp. 149-168). New York: Plenum Press.

Hilbish, T. J., Carson, E. W., Plante, J. R., Weaver, L. A., \& Gilg, M. R. (2002). Distribution of Mytilus edulis, M. galloprovincialis, and their hybrids in open-coast populations of mussels in southwestern England. Marine Biology, 140(1), 137-142. doi:10.1007/s002270100631.

Jha, A. N. (2004). Genotoxicological studies in aquatic organisms: An overview. Mutation Research, Fundamental and Molecular Mechanisms of Mutagenesis, 552(1-2), 1-17.

Jha, A. N. (2008). Ecotoxicological applications and significance of the Comet assay. Mutagenesis, 23(3), 207-221. doi:10.1093/mutage/gen014.

Jha, A. N., Cheung, V. V., Foulkes, M. E., Hill, S. J., \& Depledge, M. H. (2000). Detection of genotoxins in the marine environment: Adoption and evaluation of an integrated approach using the embryo-larval stages of the marine mussel, Mytilus edulis. Mutation Research, Genetic
Toxicology and Environmental Mutagenesis, 464(2), 213228.

Jung, K., Stelzenmuller, V., \& Zauke, G. P. (2006). Spatial distribution of heavy metal concentrations and biomass indices in Cerastoderma edule Linnaeus (1758) from the German Wadden Sea: An integrated biomonitoring approach. Journal of Experimental Marine Biology and Ecology, 338(1), 81-95. doi:10.1016/j.jembe.2006.06.036.

Kumaravel, T. S., \& Jha, A. N. (2006). Reliable comet assay measurements for detecting DNA damage induced by ionising radiation and chemicals. Mutation Research, Genetic Toxicology and Environmental Mutagenesis, 605(1-2), 716. doi:10.1016/j.mrgentox.2006.03.002.

Kumaravel, T. S., Vilhar, B., Faux, S. P., \& Jha, A. N. (2009). Comet assay measurements: A perspective. Cell Biology and Toxicology, 25(1), 53-64. doi:10.1007/s10565-0079043-9.

Langston, W. J., Chesman, B. S., Burt, G. R., Hawkins, S. J., Readman, J., \& Worsfold, P. J. (2003). Characterisation of the South West European Marine Sites. Plymouth Sound and Estuaries cSAC, SPA. Plymouth: Marine Biological Association of the United Kingdom.

Law, R. J., Dawes, V. J., Woodhead, R. J., \& Mattiessen, P. (1997). Polcyclic aromatic hydrocarbons (PAH) in seawater around England and Wales. Marine Pollution Bulletin, 34(5), 306-322.

Lindsay, P., \& Bell, F. G. (1997). Contaminated sediment in two United Kingdom estuaries. Environmental and Engineering Geoscience, 3(3), 375-387.

Liu, Y. P., Millward, G. E., \& Harris, J. R. W. (1998). Modelling the distributions of dissolved $\mathrm{Zn}$ and $\mathrm{Ni}$ in the Tamar Estuary using hydrodynamics coupled with chemical kinetics. Estuarine, Coastal and Shelf Science, 47(5), 535546. doi:10.1006/ecss.1998.0372.

Lobo, J., Costa, P., Caeiro, S., Martins, M., Ferreira, A., Caetano, M., et al. (2010). Evaluation of the potential of the common cockle (Cerastoderma edule L.) for the ecological risk assessment of estuarine sediments: Bioaccumulation and biomarkers. Ecotoxicology, 19(8), 1496-1512. doi:10.1007/s10646-010-0535-7.

Lowe, D. M. (1988). Alterations in cellular structure of Mytilus edulis resulting from exposure to environmental contaminants under field and experimental conditions. Marine Ecology Progress Series, 46, 91-100.

Lowe, D. M., \& Pipe, R. K. (1994). Contaminant induced lysosomal membrane damage in marine mussel digestive cells: An in vitro study. Aquatic Toxicology, 30(4), 357365. doi:10.1016/0166-445x(94)00045-x.

Lowe, D. M., Fossato, V. U., \& Depledge, M. H. (1995). Contaminant-induced lysosomal membrane damage in blood cells of mussels Mytilus galloprovincialis from the Venice Lagoon: An in vitro study. Marine Ecology Progress Series, 129(1-3), 189-196.

Lyons, B. P., Thain, J. E., Stentiford, G. D., Hylland, K., Davies, I. M., \& Vethaak, A. D. (2010). Using biological effects tools to define good environmental status under the European Union marine strategy framework directive. Marine Pollution Bulletin, 60(10), 1647-1651. doi:10.1016/ j.marpolbul.2010.06.005.

Millward, G. E., Kadam, S., \& Jha, A. N. (2012). Tissuespecific assimilation, depuration and toxicity of nickel in 
Mytilus edulis. Environmental Pollution, 162, 406-412. doi:10.1016/j.envpol.2011.11.034.

Money, C., Braungardt, C. B., Jha, A. N., Worsfold, P. J., \& Achterberg, E. P. (2011). Metal speciation and toxicity of Tamar Estuary water to larvae of the Pacific oyster, Crassostrea gigas. Marine Environmental Research, 72(1-2), 3-12. doi:10.1016/j.marenvres.2011.05.001.

Moore, M. N., \& Lowe, D. (2004). ICES techniques in marine environmental sciences. No. 36. Biological effects of contaminants: Measurement of lysosomal membrane stability. Copenhagen: International Council for Exploration of the Sea.

Moore, M. N., Widdows, J., Cleary, J. J., Pipe, R. K., Salkeld, P. N., Donkin, P., et al. (1984). Responses of the mussel Mytilus edulis to copper and phenanthrene: Interactive effects. Marine Environmental Research, 14, 147-183.

Moore, M. N., Depledge, M. H., Readman, J. W., \& Paul Leonard, D. R. (2004). An integrated biomarker-based strategy for ecotoxicological evaluation of risk in environmental management. Mutation Research, Fundamental and Molecular Mechanisms of Mutagenesis, 552(1-2), 247-268. doi:10.1016/j.mrfmmm.2004.06.028.

Nacci, D. E., \& Jackim, E. (1989). Using the DNA alkaline unwinding assay to detect DNA damage in laboratory and environmentally exposed cells and tissues. Marine Environmental Research, 29, 333-337.

Nacci, D. E., Kohan, M., Pelletier, M., \& George, E. (2002). Effects of benzo[a]pyrene exposure on a fish population resistant to the toxic effects of dioxin-like compounds. Aquatic Toxicology, 57(4), 203-215.

Nevo, E., Noy, R., Lavie, B., Beiles, A., \& Muchtar, S. (1986). Genetic diversity and resistance to marine pollution: Theory and practice. Biological Journal of the Linnean Society, 29, 139-144.

Papis, E., Davies, S. J., \& Jha, A. N. (2011). Relative sensitivity of fish and mammalian cells to the antibiotic, trimethoprim: Cytotoxic and genotoxic responses as determined by neutral red retention, Comet and micronucleus assays. Ecotoxicology, 20, 208-217.

Phillips, D. J. H. (1977). The use of biological indicator organisms to monitor trace metal pollution in marine and estuarine environments-A review. Environmental Pollution, 13, 281-317. doi:10.1016/0013-9327(77)90047-7.

Pipe, R. K., Porte, C., \& Livingstone, D. R. (1993). Antioxidant enzymes associated with the blood cells and haemolymph of the mussel Mytilus edulis. Fish \& Shellfish Immunology, 3(3), 221-233. doi:10.1006/fsim.1993.1022.
Rank, J., Jensen, K., \& Jespersen, P. H. (2005). Monitoring DNA damage in indigenous blue mussels (Mytilus edulis) sampled from coastal sites in Denmark. Mutation Research, Genetic Toxicology and Environmental Mutagenesis, 585(1-2), 33-42. doi:10.1016/ j.mrgentox.2005.04.008.

Sasaki, Y. F., Izumiyama, F., Nishidate, E., Ishibashi, S., Tsuda, S., Matsusaka, N., et al. (1997). Detection of genotoxicity of polluted sea water using shellfish and the alkaline single-cell gel electrophoresis (SCE) assay: A preliminary study. Mutation Research, 393(1-2), 133-139.

Shaw, J. P., \& Moore, M. N. (2011). Introduction to the Department for Environment, Food and Rural Affairs (Defra) PREDICT 2 Tamar Estuary Research Workshop: Pathological risk evaluation using "health status-related" biomarkers. Marine Environmental Research, 72(1-2), 1-2. doi:10.1016/j.marenvres.2011.05.002.

Shaw, J. P., Dondero, F., Moore, M. N., Negri, A., Dagnino, A., Readman, J. W., et al. (2011). Integration of biochemical, histochemical and toxicogenomic indices for the assessment of health status of mussels from the Tamar Estuary, U.K. Marine Environmental Research, 72(1-2), 13-24. doi:10.1016/j.marenvres.2011.05.003.

Steinert, S. A., Streib-Montee, R., Leather, J. M., \& Chadwick, D. B. (1998). DNA damage in mussels at sites in San Diego Bay. Mutation Research, 399, 65-85.

Sternlieb, I., \& Goldfischer, S. (1976). Heavy metals and lysosomes. Frontiers in Biology, 45, 185-200.

Viarengo, A. (1985). Biochemical effects of trace metals. Marine Pollution Bulletin, 16(4), 153-158.

Webb, M. (1979). The chemistry, biochemistry and biology of cadmium. Amsterdam: Elsevier.

Wedderburn, J., Cheung, V., Bamber, S., Bloxham, M., \& Depledge, M. H. (1998). Biomarkers of biochemical and cellular stress in Carcinus maenas: An in situ field study. Marine Environmental Research, 46(1-5), 321-324. doi:10.1016/s0141-1136(98)00016-6.

Woodhead, R. J., Law, R. J., \& Mattiessen, P. (1999). Polycyclic aromatic hydrocarbons in surface sediments around England and Wales, and their possible biological significance. Marine Pollution Bulletin, 38(9), 773-790.

Wootton, E. C., Dyrynda, E. A., \& Ratcliffe, N. A. (2003). Bivalve immunity: Comparisons between the marine mussel (Mytilus edulis), the edible cockle (Cerastoderma edule) and the razor-shell (Ensis siliqua). Fish \& Shellfish Immunology, 15(3), 195-210. doi:10.1016/s1050-4648 (02)00161-4. 